\title{
Comportement in vitro d'embryons zygotiques de chêne liège (Quercus suber L.) excisés à divers stades de leur développement
}

\author{
M. El Maâtaoui et H. Espagnac
}

Laboratoire de Biologie Végétale Expérimentale, Faculté des Sciences, 33, rue Louis-Pasteur, 84000 Avignon, France

\section{Introduction}

La culture in vitro d'embryons zygotiques immatures est de plus en plus utilisée en vue d'appréhender certains problèmes morphogénètiques (Monnier, 1988) et en particulier l'embryogenèse somatique (Williams et Maheswaran, 1986). Dans la pratique, cette technique est largement exploitée pour l'obtention d'hybrides interspécifiques dont la viabilité est souvent compromise à cause de leur incompatibilité avec les tissus maternels (Bhojwani et Razdan, 1983). Récemment, le développement considérable des recherches en embryogénèse somatique a suscité un regain d'intérêt pour les embryons zygotiques. Dans ce domaine, ils sont non seulement utilisés pour initier les processus embryogènes chez de nombreuses espèces (Williams et Maheswaran, 1986) mais aussi pour aborder les aspects nutritionnels et comportementaux dont la connaissance est nécessaire avant toute introduction des embryons somatiques dans les programmes de multiplication des végétaux (Ammirato, 1983). C'est dans cette double optique que nous avons pratiqué la culture d'embryons zygotiques de chêne liège, excisés plus ou moins précocement. Nous avons en effet, dans un précédent travail (El Maâtaoui et Espagnac, 1987), réussi à induire une embryogenèse somatique chez cette espèce à partir d'explants caulinaires. Mais les embryons somatiques obtenus, au lieu de se développer normalement et régénérer des plantes, devenaient rapidement le siège d'une importante embryogenèse adventive ou secondaire. D'autre part, dans nos conditions expérimentales, seul un nombre réduit d'explants (environ 3\%) donnait naissance à des cultures embryogènes.

C'est donc d'une part pour tester le comportement in vitro d'embryons zygotiques immatures en vue de le comparer ultérieurement à celui observé chez leurs homologues somatiques et d'autre part pour disposer d'un procédé reproductible d'embryogenèse somatique chez le chêne liège que nous avons entrepris cette étude. 


\section{Matériel et Méthodes}

Des glands immatures ont été régulièrement récoltés tous les 10 jours, durant une période allant du début juillet à la fin septembre, sur des arbres adultes situés dans le Massif des Maures (Collobrières). Ils ont été débarrassés de leurs cupules, stérilisés pendant $20 \mathrm{~min}$ à l'hypochlorite de calcium à $40 \%$ et disséqués aseptiquement. Les embryons de 0,06 à $5 \mathrm{~mm}$ de long ont été séparés en 3 catégories selon leur stade de développement en embryons globulaires, embryons cordiformes et embryons cotylédonaires. En outre, les embryons cotylédonaires ont été à leur tour séparés en 3 classes notées $C_{1}, C_{2}$ et $C_{3}$ : début de diftérenciation des cotylédons, aspect translucide net $\left(C_{1}\right)$; cotylédons différenciés, aspect encore translucide $\left(\mathrm{C}_{2}\right)$; cotylédons développés, aspect blanc laiteux $\left(\mathrm{C}_{3}\right)$.

La culture a été réalisée en boîtes de Pétri, sur le milieu minéral de Murashige et Skoog (1962) solidifié avec la gélose à $7 \mathrm{~g}^{\cdot 1}{ }^{-1}$ et additionné de glucose à $30 \mathrm{~g} \cdot \mu^{-1}$, d'hydrolysat de caséine à $0,5 \mathrm{~g} \cdot \mathrm{H}^{-1}$ et d'un mélange d'acide indolylbutyrique (AIB) et de benzylaminopurine (BAP) à $2 \mathrm{mg} \cdot{ }^{1-1}$. Après ensemencement, les boîtes de Petri, à raison de 4 boîtes par catégorie d'embryons contenant chacune 15 explants, ont été maintenues à l'obscurité dans une salle climatisée (température oscillant entre 25 et $28^{\circ} \mathrm{C}$ ). L'examen histologique a été réalisé sur des embryons fixés dans le mélange FAA $(10 \%$ formol $+5 \%$ acide acétique $+85 \%$ alcool à $50^{\circ}$ ) et inclus à la paraffine. Les coupes, de $10 \mu \mathrm{m}$ d'épaisseur, ont été colorées à l'hématoxylinesafranine-bleu d'aniline.

\section{Résultats et Discussion}

D'après les données rassemblées dans le Tableau I, on note que les embryons excisés au stade globulaire ne se développent pas dans nos conditions expérimentales, probablement à cause de l'inadéquation du milieu de culture (Monnier, 1988).

Au stade cordiforme, ils présentent aussi une mortalité non négligeable $(17 \%)$; ceux qui survivent donnent tous naissance à des cals amorphes, compacts, de couleur blanchâtre, ne présentant par la suite aucune potentialité morphogène.

Signalons que des réactions similaires ont été obtenues avec des embryons globulaires et cordiformes d'autres espèces comme l'orge (Cameron-Mills et Duffus, 1977) ou le soja (Tilton et Russell, 1984).

Isolés au stade cotylédonaire, les embryons fournissent une réponse dépendant de leur degré de maturation. Les plus jeunes $\left(C_{1}\right)$, encore translucides, réagissent dans $95 \%$ des cas par la production d'embryons somatiques qui apparaissent très rapidement (à partir du $5 \mathrm{e}$ jour de culture) sur toute la surface des explants (Figs. 1 et 2). Extraits de leur milieu habituel et placés sur un milieu artificiel en

Tableau I. Réponses (pourcentages calculés pour 60 explants) des embryons en fonction de leur stade de développement.

\begin{tabular}{lccccc}
\hline & $\begin{array}{l}\text { Stade globulaire } \\
(60-300 \mu \mathrm{m})\end{array}$ & $\begin{array}{l}\text { Stade cordiforme } \\
(300-500 \mu \mathrm{m})\end{array}$ & \multicolumn{2}{l}{$\begin{array}{l}\text { Stades cotylédonaires } \\
(0,5-5 \mathrm{~mm})\end{array}$} \\
\cline { 4 - 6 } & 100 & 17 & $C_{1}$ & $C_{2}$ & $C_{3}$ \\
\hline Mortalité & - & 83 & 5 & 0 & 0 \\
$\begin{array}{l}\text { Cals non morphogènes } \\
\text { Maturation et germination }\end{array}$ & - & 0 & 0 & 0 & 0 \\
$\begin{array}{l}\text { Embryogenèse somatique } \\
\text { généralisée }\end{array}$ & - & 0 & 0 & 52 & 94 \\
$\begin{array}{l}\text { Embryogenèse somatique } \\
\text { localisée à la radicule }\end{array}$ & - & 0 & 93 & 36 & 0 \\
\hline
\end{tabular}



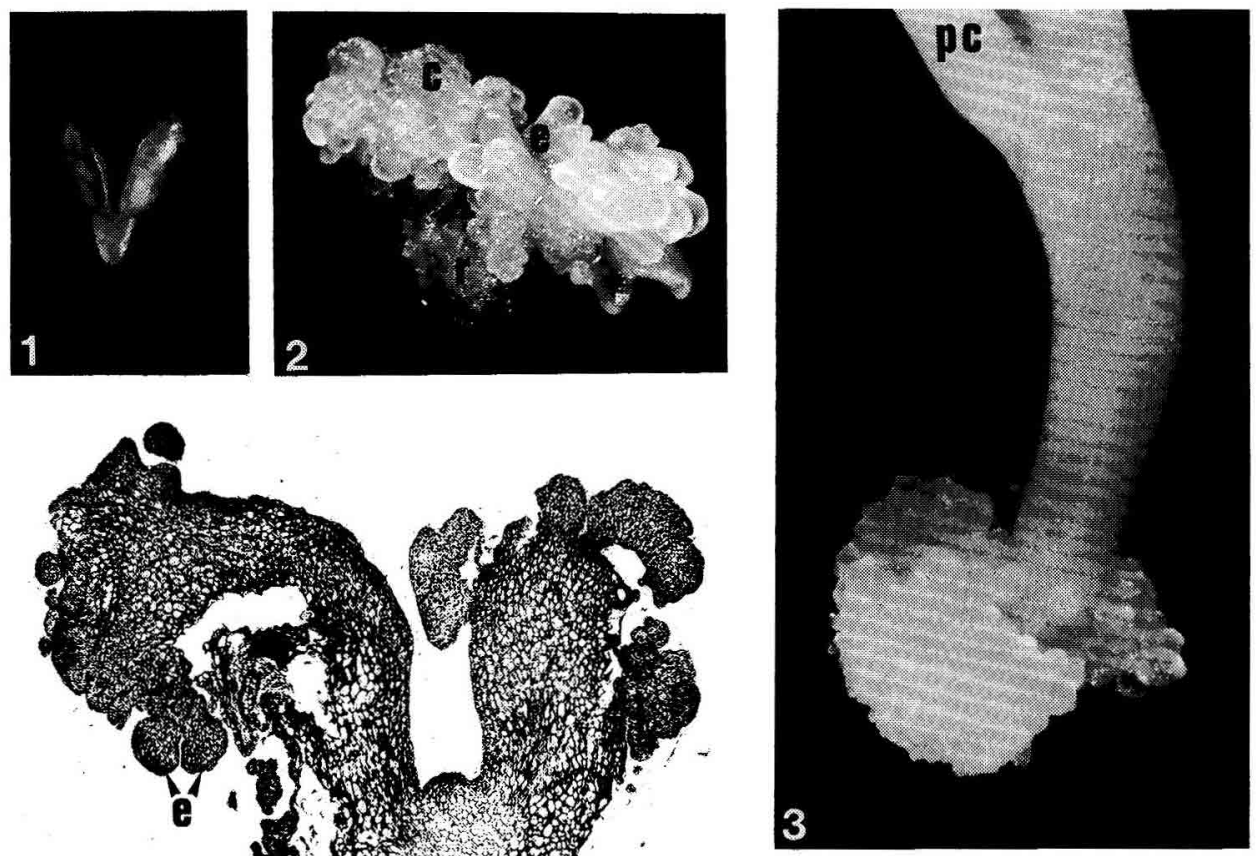

4

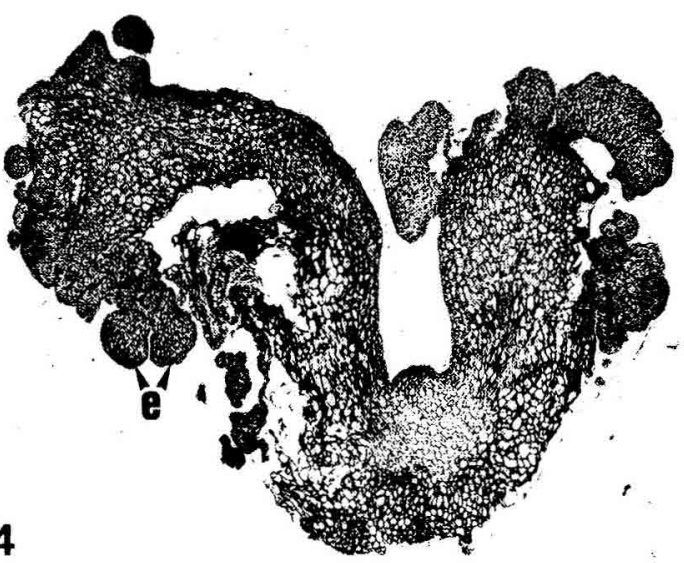

Figs. 1. Embryon zygotique excisé au stade cotylédonaire translucide $(G \times 3,5)$. 2. Embryon zygotique après 2 semaines de culture montrant une embryogenèse somatique généralisée $(G \times 2,1) . C=$ cotylédons, $r=$ radicule, $e=$ embryon somatique. 3. Partie racinaire d'un embryon zygotique excisé au stade cotylédonaire blanc laiteux et cultivé pendant $15 \mathrm{j}(\mathrm{G} \times 3.5)$. Notez la localisation de l'embryogenèse somatique à l'apex racinaire $(p c=p o n t s$ cotylédonaires). 4. Coupe longitudinale d'un embryon zygotique ayant donné naissance à une embryogenèse somatique généralisée $(G \times 28$ ). Notez que les embryons somatiques (e) se forment d'une manière directe, sans cal préalable.

présence de phyto'normones exogènes, ces embryons devient donc de leur voie normale et entament un processus de multiplication végétative. Leur comportement rappelle alors celui d'embryons somatiques obtenus sur des cals d'origine caulinaire (El Maâtaoui et Espagnac, 1987).

Les plus âgés $\left(\mathrm{C}_{3}\right)$, qui ont acquis un aspect laiteux, témoignant d'une présence d'amidon, poursuivent à $94 \%$ une évolution normale et germent. Une faible proportion d'entre eux $(6 \%)$ donne naissance à des embryons somatiques essentielle- ment localisés à la périphérie de l'apex racinaire (Fig. 3). L'accumulation de réserves semble donc s'accompagner d'une atténuation des aptitudes embryogènes au profit d'un développement normal. Ceci est en accord avec les travaux de Maheswaran et Williams (1986) sur Brassica campestris et de Merkle et Sommer (1986) sur Liriodendron tulipifera.

Prélevés à un stade intermédiaire $\left(C_{2}\right)$, les embryons présentent un comportement qui se situe entre les deux précédents: environ $50 \%$ se développent normalement alors que les autres forment 
des embryons somatiques. Mais souvent, dans ce dernier cas, l'embryogenèse somatique apparaît plus tardivement qu'avec les explants de catégorie $C_{1}$ (après $15 \mathrm{j}$ ) et affecte exclusivement la zone racinaire (apex, parfois l'hypocotyle) qui semble conserver le plus longtemps des aptitudes morphogènes.

L'étude histologique montre que, dans tous les cas, les embryons somatiques se développent d'une manière directe (Fig. 4), sans cal préalable. Comme pour d'autres exemples d'embryogenèse somatique directe (Williams et Maheswaran, 1986), ils proviennent soit d'amas pluricellulaires superficiels soit de cellules épidermiques devenues embryogènes.

Cette étude montre clairement que la culture d'embryons zygotiques immatures répond à l'un des objectifs que nous nous sommes fixés au départ concernant la recherche d'explants aptes à produire des embryons somatiques. En outre, il ressort que le stade de développement et donc l'état physiologique au moment de l'excision jouent un rôle considérable sur leur comportement. Dans nos conditions de culture, il apparaît que callogenèse et embryogenèse somatique caractérisent les explants isolés à leurs premiers stades ontogéniques. Ces derniers se distinguent en effet par une croissance rapide au cours de laquelle les activités mitotiques sont très importantes (Bhojwani et Razdan, 1983). De plus, la majorité des cellules constituant de tels embryons seraient alors selon Williams et Maheswaran (1986) encore "embryogéniquement compétentes" ce qui pourrait expliquer les réponses obtenues chez le chêne liège. Par contre, au fur et à mesure que l'on s'adresse à des stades plus avancés où la différenciation cellulaire (accumulation de réserves) commence à l'emporter sur l'activité mitotique (Bhojwani et Razdan, 1983), les embryons présentent une évolution normale. Toutefois, on note une per- sistance de potentialités morphogénétiques (embryogenèse somatique) dont l'expression tend à se localiser aux tissus superficiels de l'apex racinaire, c'est-à-dire là où les cellules possèdent encore des caractéristiques méristématiques.

\section{Références}

Ammirato P.V. (1983) The regulation of somatic embryo development in plant cell cultures: suspension culture techniques and hormone requirements. Bio/Technology, 3, 68-74

Bhojwani S.S. \& Razdan M.K. (1983) Zygotic embryo culture. In: Plant Tissue Culture: Theory and Practice. Developments in Crop Science Vol. 5. (Bhojwani S.S. \& Razdan M.K., eds.), Elsevier, Amsterdam, pp. 199-235

Cameron-Mills V. \& Duffus C.M. (1977) The in vitro culture of immature barley embryos on different culture media. Ann. Bot. 41, 1117-1127

El Maâtaoui M. \& Espagnac H. (1987) Néoformation de structures de type embryons somatiques sur des cultures de tissus de chêne liège (Quercus suber L..) C.R. Acad. Sci. Sér. III 304, 83-88

Maheswaran G. \& Williams E. (1986) Primary and secondary direct somatic embryogenesis from immature zygotic embryos of Brassica campestris. J. Plant Physiol. 124, 455-463

Merkle S.A. \& Sommer H.E. (1986) Somatic embryogenesis in tissue cultures of Liriodendron tulipifera. Can. J. For. Res. 16, 420-422

Monnier M. (1988) Culture d'embryons et d'ovules. In: Culture de cellules, tissus et organes végétaux. (Zryd J.P., ed.) Presses Polytechniques Romandes, Lausanne, pp. 103107

Murashige T. \& Skoog F. (1962) A revised medium for rapid growth and bioassays with tobacco tissue cultures. Physiol. Plant. 15, 473497

Tilton V.R. \& Russell S.H. (1984) In vitro culture of immature soybean embryos. J. Plant Physiol. 115, 191-200

Williams E.G. \& Maheswaran G. (1986) Somatic embryogenesis: factors influencing coordinated behaviour of cells as an embryogenic group. Ann. Bot. 57, 443-462 